\title{
The Mesoproterozoic sub-Heddersvatnet unconformity, Telemark, South Norway
}

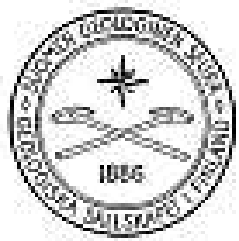

\author{
Kauko LaAjoki \\ Department of Geosciences, University of Oulu, P.O. Box 3000, 90014 University of Oulu, \\ Finland
}

\begin{abstract}
The I.5I Ga Rjukan group, Telemark, S Norway, is divided into felsic volcanic rocks of the Tuddal formation and mafic rocks of the Vemork formation. It is overlain by the sedimentary rocks of the Vindeggen group (1.50-1.17 Ga), starting with the arkosic Heddersvatnet formation. The contact between the Rjukan and Vindeggen groups has been variably interpreted in the literature. New field data indicate that the contact corresponds to an unconformity, corroborating Wyckoff's early observations in 1934. The contact is referred to as the sub-Heddersvatnet unconformity.

The nature of the contact varies. Around Lake Heddersvatnet, it most likely represents an angular unconformity with a sharp, erosional surface, whereas near Lake Skjesvatnet a thin in situ palaeoweathering crust developed on a massive Tuddal porphyry defines it. These observations indicate that the sub-Heddersvatnet unconformity represents a deeply weathered land surface cutting diverse folded Tuddal units. How big is the time gap it represents and the nature of the pre-Vindeggen deformation are open questions as the sedimentation age of the Heddersvatnet formation is unknown and the structure of the Rjukan group has not been studied on a regional scale.
\end{abstract}

Key words: metasedimentary rocks, metavolcanic rocks, lithostratigraphy, unconformities, Mesoproterozoic, Rjukan, Vindeggen, Telemark, Norway 


\section{Introduction}

The Telemark sector of the Sveconorwegian basement in southern Norway is known for the greenschist- to epidote-amphibolite facies sequence of Mesoproterozoic volcanic and sedimentary rocks known as the Telemark supracrustal belt. Traditionally, these rocks are divided into the Rjukan (oldest), Seljord, and Bandak (youngest) groups (Dons, 1960a, b). Early authors (Wyckoff, 1934; Dons, 1960a, b) interpreted the contacts between these units as unconformities. The Rjukan group included two formations, the Tuddal formation made up of felsic metavolcanic rocks overlain by the mafic metavolcanic and arenitic metasedimentary rocks of the Vemork formation of (Dons, 1960a, b). The Seljord group consisted three quartzite and three schist (mudstone) formations. Dahlgren et al. (1990a) suggested that the Vemork formation does not belong to the Rjukan Group, but should be included in the Seljord group. However, as according to Dons $(1960 \mathrm{a}, \mathrm{b})$ no unconformity can be seen between the Tuddal and Vemork formations they both are kept within the original Rjukan group in this paper. Recently the Seljord group has been subdivided into the Vindeggen (older) and Lifjell (younger) groups (Laajoki et al., 2002). This paper addresses the unconformity between the Tuddal formation of the Rjukan group and the Heddersvatnet formation, the lowermost unit of the Vindeggen group.

\section{Geological setting and lithostratigraphy}

The study area is located in the northern part of the Sveconorwegian Telemark sector (Andersen, 2003) of the Southwest Scandinavian Domain (Gaál \& Gorbatschev, 1987) of the Fennoscandian (Baltic) Shield (Fig. 1). Most of the Precambrian crust in South Norway has been affected by Sveconorwegian deformation and metamorphism (1.2-0.9 Ga), which have obliterated primary stratigraphic relationships (e.g. Starmer, 1993). The northern part of the Telemark sector forms, however, an exception, as it is underlain by rather well preserved volcanic and sedimen- tary rocks known as the Telemark supracrustals (Sigmond et al., 1997).

Recent studies (Dahlgren et al., 1990a; Bingen et al., 2001; 2003; 2005, Laajoki et al., 2002; Laajoki, 2002) have shown that the Telemark stratigraphy is more complicated than Dons' (1960a, b) tripartite subdivision into the Rjukan, Seljord, and Bandak groups and the existence of a major angular unconformity between the Rjukan and Seljord groups has been questioned (Starmer, 1993; Menuge \& Brewer, 1996; Brewer \& Menuge, 1998). For the purpose of this study it is enough to say that the most important angular unconformity within the Telemark belt is the sub-Svinsaga unconformity (Laajoki et al., 2002), which subdivides the Telemark supracrustals into the Vestfjorddalenian and Sveconorwegian sequences (Laajoki \& Lamminen, 2005), of which the former comprises the c. 1.51 Ga old (Dahlgren et al., 1990a; Sigmond, 1998; Bingen et al., 2005) felsic volcanites of the Tuddal formation, the mafic metavolcanites, and interbedded metasediments of the Ve-

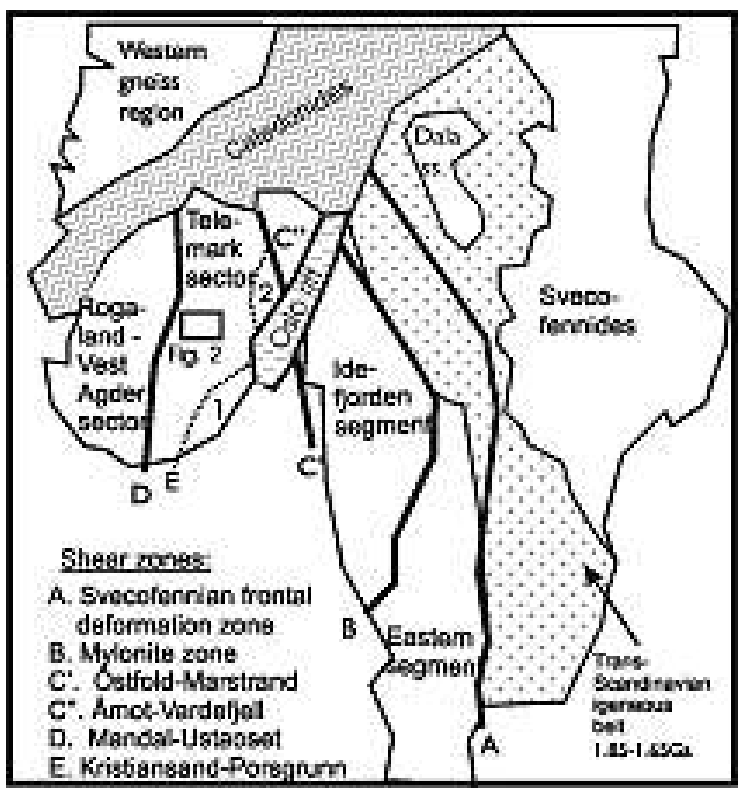

Fig. I. Sketch map of the Sveconorwegian province (modified from Bingen et al., 200I). The area covered by Fig. 2 is framed. Numbered sectors west of the Oslo rift: (1) Bamble, (2) Kongsberg, 
mork formation of the Rjukan group and the overlying quartzite-dominated Vindeggen group (see legend in Fig. 2). The Sveconorwegian units will not be treated in this paper, as the main target is the intraVestfjorddalenian unconformity between the Rjukan and Vindeggen groups.

Dons' (1960a, b) established the classical lithostratigraphic nomenclature of the Telemark supracrus- tals. Unfortunately, none of the units have been established formally in the sense of the present Norwegian recommendations (Nystuen, 1986, 1989) and only brief descriptions are available. That is why all the unit names used in this paper are informal. Dons (1960a, b) included the basal conglomerates and associated arkosites that locally overlie the Rjukan group in the lower part of his Gausta formation. However,

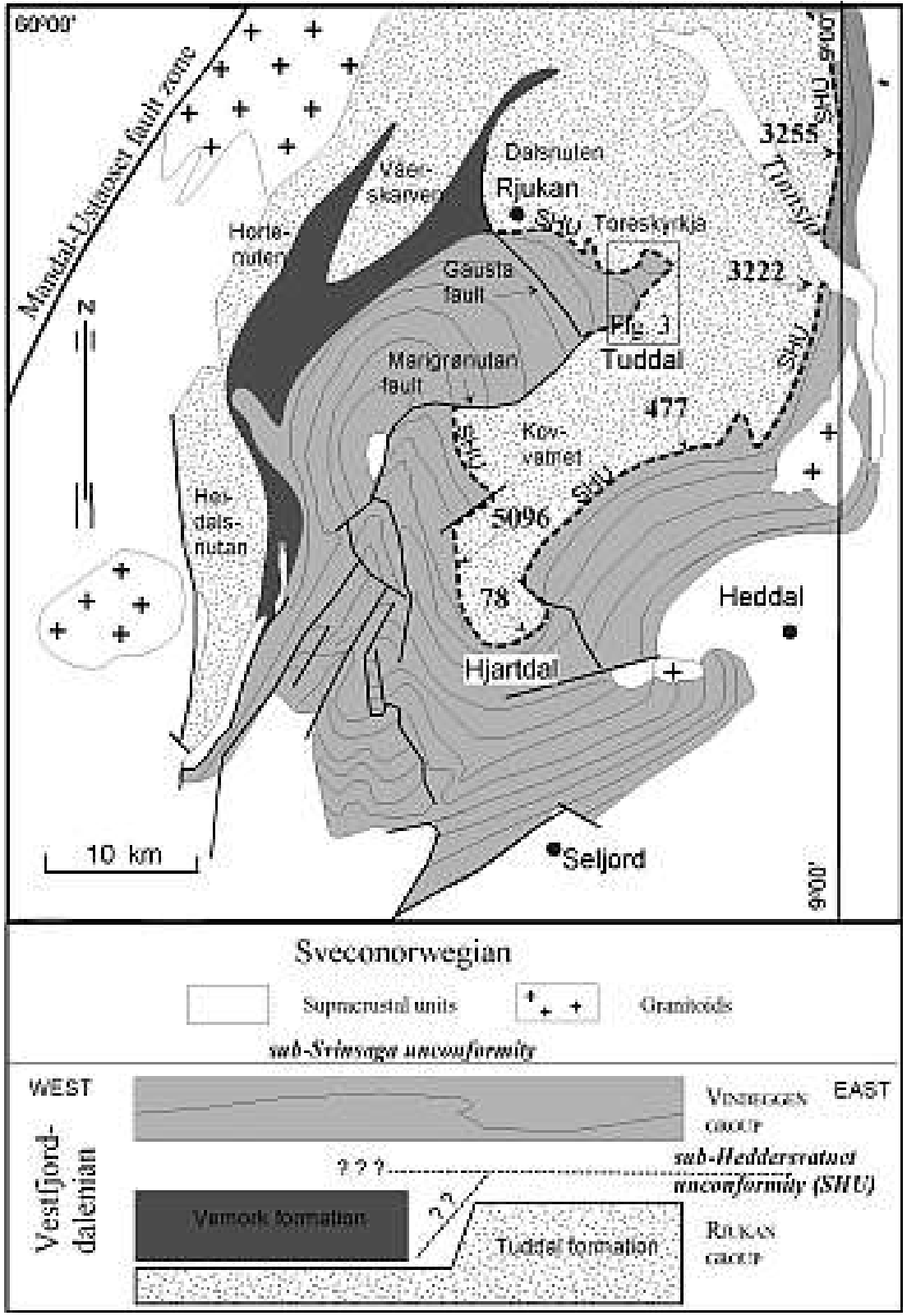

Fig. 2. Simplified geological map of the southern part of the Rjukan rift basin in central Telemark (simplified and modified from Dons \& Jorde, 1978). The sub-Heddersvatnet unconformity (SHU) is shown by dashed line and the area of Fig. 3 and locations of the stations (bold numbers) discussed in the text are indicated. Thick lines mark faults. Form lines within the Vindeggen group indicate bedding trends. 
Table I. Previous short statements of the relationships between the Rjukan group/Tuddal formation/Vemork formation, and Seljord group (Vindeggen group in present usage).

\begin{tabular}{|c|c|c|c|}
\hline $\begin{array}{l}\text { Rjukan gr. /Seljord gr. con- } \\
\text { tact. }\end{array}$ & $\begin{array}{l}\text { Tuddal fm. /Vemork fm. } \\
\text { contact. }\end{array}$ & Vemork fm. vs. Seljord gr. & Tuddal fm. vs. Seljord gr. \\
\hline $\begin{array}{l}\text { Werenskiold, } 1910, \text { p } 11 . \\
\text { A likely discordance } \\
\text { Wyckoff, } 1934, \text { p. } 15 . \\
\text { A large unconformity. } \\
\text { Dons, } 1960 \text { a, p. 6; b, p. } 6 . \\
\text { An angular unconformity. } \\
\text { Brewer \& Menuge, } 1998 . \\
\text { The Rjukan and Seljord } \\
\text { groups represent one pack- } \\
\text { age within which the discor- } \\
\text { dance }{ }^{1)} \text { of individual units } \\
\text { is a function of the mode of } \\
\text { deposition. } \\
\text { Sigmond, } 1998 . \\
\text { The Seljord gr. lies discor- } \\
\text { dantly }{ }^{1)} \text { on the Rjukan gr. } \\
\text { Falkum \& Petersen, } 1980, \\
\text { p. } 630 . \\
\text { Major angular unconformi- } \\
\text { ty could be interpreted as the } \\
\text { result of fault tectonics. } \\
\text { Richards, } 1994 . \text { The Rju- } \\
\text { kan gr. was deformed before } \\
\text { the deposition of the Seljord } \\
\text { group. }\end{array}$ & $\begin{array}{l}\text { Dons, } 1960 \mathrm{a}, \mathrm{p} .50 . \\
\text { The Vemork fm. rests con- } \\
\text { formably on the Tuddal fm. } \\
\text { Brewer, } 1985, \text { p. } 12 . \\
\text { The Vemork fm. rests un- } \\
\text { conformably on the Tud- } \\
\text { dal fm. } \\
\text { Brewer \& Menuge, } 1998 . \\
\text { The Vemork fm. lies discon- } \\
\text { formably }{ }^{1)} \text { upon the Tud- } \\
\text { dal fm. }\end{array}$ & $\begin{array}{l}\text { Dahlgren et al., 1990a. } \\
\text { The Vemork fm. represents } \\
\text { initial volcanism and sedi- } \\
\text { mentation of the Seljord gr. }\end{array}$ & $\begin{array}{l}\text { Starmer, } 1993 \text {. } \\
\text { The Seljord gr. lies uncon- } \\
\text { formably on an irregular vol- } \\
\text { canic topography of the Rju- } \\
\text { kan gr., which has an ero- } \\
\text { sional surface. } \\
\text { Menuge \& Brewer, } 1996 . \\
\text { As above, but the contact } \\
\text { was considered as discon- } \\
\text { formable }{ }^{1)} \text {. } \\
\text { Cf. Brewer \& Menuge } 1998 \\
\text { in the first column. }\end{array}$ \\
\hline
\end{tabular}

1) Stratified rocks being rare in the Tuddal formation, discordance and disconformable are a little confusing expressions in this connection as they refer, respectively, to lack of parallelism between adjacent strata and to formations that exhibit essentially parallel bedding (Jackson, 1997).

as these rocks form an important mappable unit they are considered as a formation of their own named the Heddersvatnet formation (Laajoki et al., 2002) after the lake around which they are best exposed (Fig. 3). For more detailed lithostratigraphy of the Vindeggen and overlying groups it is referred to Laajoki et al. (2002), Lamminen and Laajoki (2004), and Laajoki and Lamminen (2005).

The Tuddal formation, the c. 1.5 Ga old floor of the study area, occurs as dome-like fold structures, of which the Kovvatnet and Toreskyrkja domes are mantled by the Heddersvatnet formation, whereas the Heidalsnutan-Hortenuten and Vårskarven domes are rimmed by the Vemork formation (Fig. 2). This means that the Vindeggen group directly over- lies on the Tuddal formation and the Vemork formation in the east and in the west, respectively (see legend in Fig. 2). It is, however, possible, that the Heddersvatnet formation interfingers with the Vemork formation (Laajoki, 2003).

All the rocks have been metamorphosed in greenschist facies and so meta-prefix should be used in the rock names, but for simplicity's sake their protolith names are used in this paper.

\section{Previous studies}

The Rjukan and Seljord (Vindeggen) groups around the town Rjukan (Fig. 2) have been mapped in rather great detail (Wyckoff, 1934; Dons, 1961) and a lot of 
geochemical work is available on the metavolcanites of the Tuddal and Vemork formations (Brewer et al., 2004 and references therein), but their lithostratigraphy and mutual contacts have not been documented as well. Table 1 presents previous concepts of the stratigraphic relationships of the units treated in this study. Connecting different opinions, it can be said that the original idea of a large angular unconformity between the Rjukan and Seljord (Vindeggen) groups (Wyckoff, 1934; Dons, 1960a, b) has not been accepted in recent literature (Starmer, 1993; Menuge \& Brewer, 1996; Brewer \& Menuge, 1998). Dahlgren et al. (1990a) included the Vemork formation in the traditional Seljord group and Brewer \& Menuge (1998) considered the Rjukan and Seljord (Vindeggen) groups as one package. However, Richards (1994, 1998) stated that the Rjukan group was deformed before the deposition of the Seljord group. This paper will treat only the Tuddal formation / Heddersvatnet formation relationship. The Tuddal formation/Vemork formation contact will be documented in another publication.

\section{Lithological and structural obser- vations of the Tuddal formation}

Wyckoff (1934) subdivided her volcanic lower series (Tuddal formation in this paper) into tuffs and five lava types. As the palaeovolcanism was not the main target of the present study and due to common lichen cover of the outcrops, a simplified, tripartite classification based on most evident lithological features was used in the field. (1) Flow banded lavas/volcanics include both rhyolitic rocks with flow-folded volcanic banding (Fig. 4a) and types with more regular banding, (2) lithophysa lavas contain lithophysae up to $20-30 \mathrm{~cm}$ in diameter (Fig. $4 \mathrm{~b}$ ), and (3) porphyries include both clearly porphyric and more massive rhyolitic lavas. Volcaniclastic interbeds were detected only in a few cases south of Heddersvatnet. They were classified into lapilli tuffs (Fig. 4c), pebbly arkosites, and debris flows (Fig. 4d).

Structure of the Tuddal volcanic complex is hard to work out, as the rocks are often massive and con- tacts of lava flows cannot be seen due to lichen cover, metamorphism and deformation. Flow banding is rather common, but it cannot be used for exact positioning of the volcanic beds, as it was already primarily distorted (Fig. 4a) (cf. Fig. 4.28 in Cash \& Wright, 1988, republished after Hall 1978). The only reliable structure for this purpose is bedding in volcaniclastic interbeds, but unfortunately these rocks are uncommon. In any case, the few bedding observations made southeast and south of Lake Heddersvatnet (Fig. 3) confirm Wyckoff's (1934) statement that the Tuddal tuffs trend about northeast and dip variably either to SE or NW or have been steeply folded (Fig. 4e). In Nutan, the debris flow unit displays part of an open recumbent fold facing to the northwest (Fig. 4d). No sedimentary interbeds were detected north of Heddersvatnet, but flow banding west of Hestegrøi is steeply dipping and seems to abut the sub-Heddersvatnet unconformity (Fig. 3). These observations indicate, that the structure of Tuddal formation differs considerably from the overlying Vindeggen group, whose two lowermost formations, the Heddersvatnet and Gausta formations, define the open, broad Vindsjå syncline (Figs. 4e, 5a) plunging shallowly to the NNE on Heddersfjellet and to the SW on Gaustaråen (Fig. 3). In Richards' (1998) regional classification the Vindsjå syncline represents an early $\mathrm{D}_{4}$ structure of the main Sveconorwegian deformation refolded by the late $\mathrm{F}_{4}$ Jonnbu anticline.

Dons (1960a, p. 50) wrote, that the unconformity between the Rjukan and Seljord (Vindeggen) groups is best developed in the valley slope northwest of Rjukan where the layers of the two groups are nearly perpendicular to each other. The author has not visited this section, but mapped the southeastern side of the same valley along the road from Gausta to Rjukan. The rocks are tightly folded sericite schists, arkosites, and conglomerates with felsic volcanic clasts. They have been folded along a fold axis plunging shallowly to the NE and the axial plane foliation dips about $40^{\circ}$ to the southeast (Fig. 5b). Dons (1961) mapped them as the Tuddal formation, but they may more likely belong to the Heddersvatnet formation. The profile in Fig. 5b 


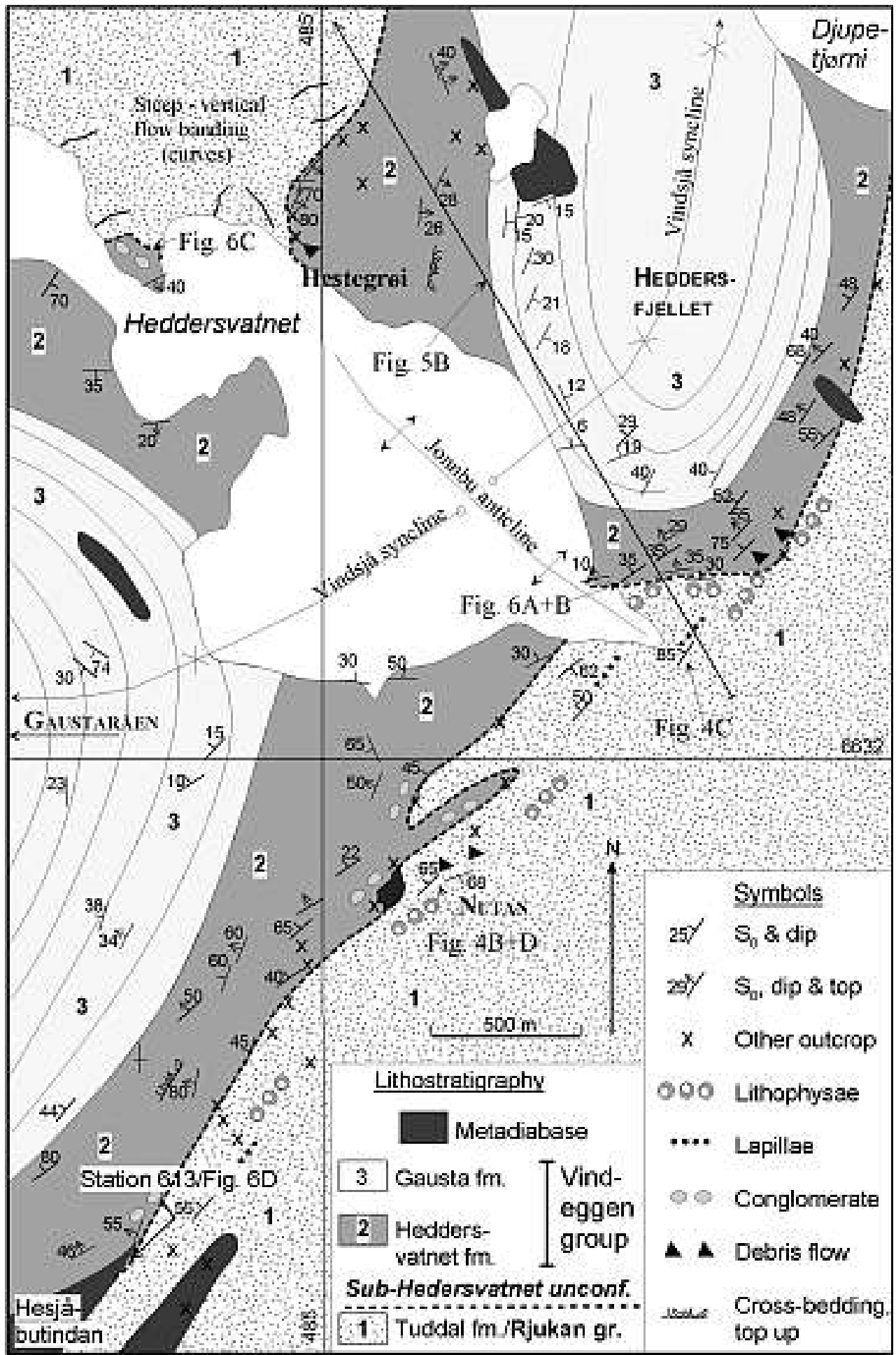

Fig. 3. Geological map of the Heddersvatnet area. The locations of photographed outcrops in Figs. 4 and 6 and the Heddersfjellet-Vestfjorddalen cross section in Fig. 5b are indicated. Form lines within the Gausta formation indicate bedding trends. Note that sub-Heddersvatnet unconformity south of Heddersvatnet has not been located exactly and that it can be sheared (Fig. 6d). 
a)

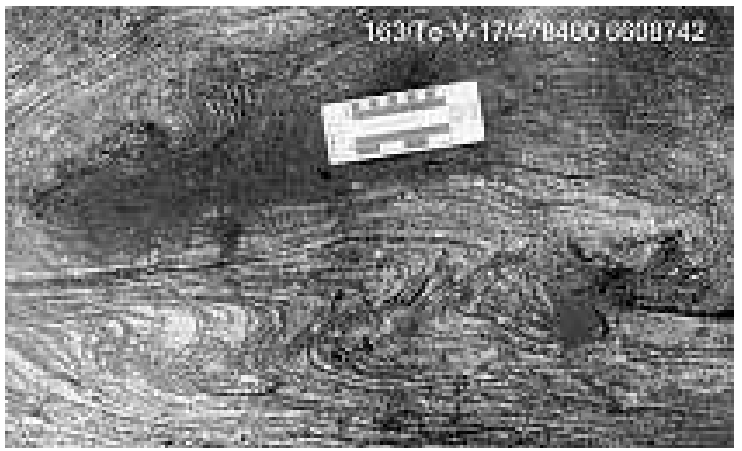

b)

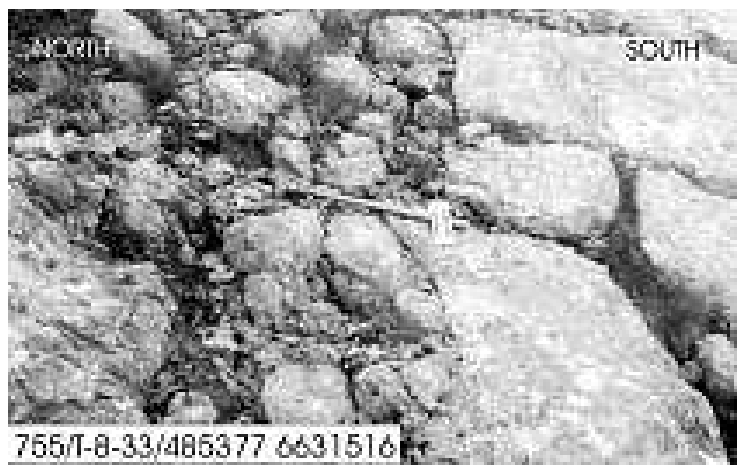

c)

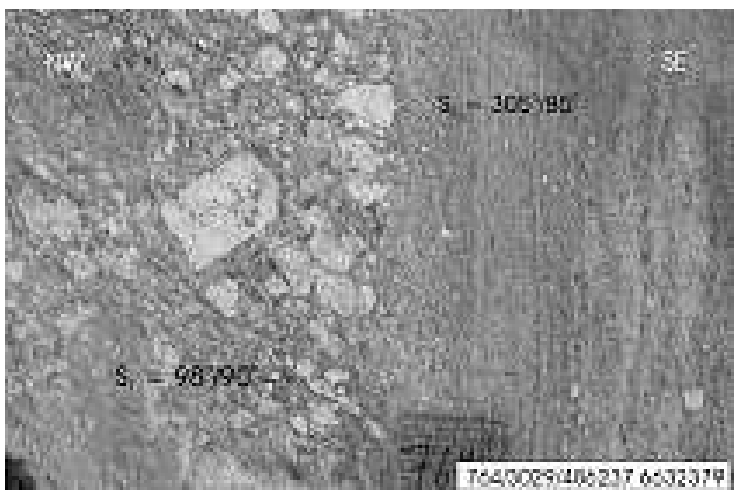

d) $\mathrm{NW}$

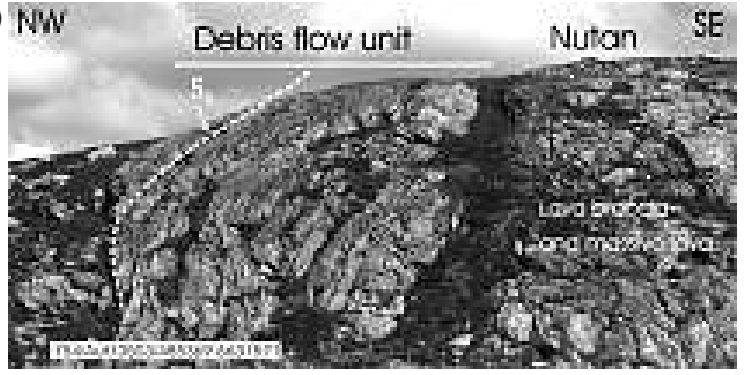

e) Soukast

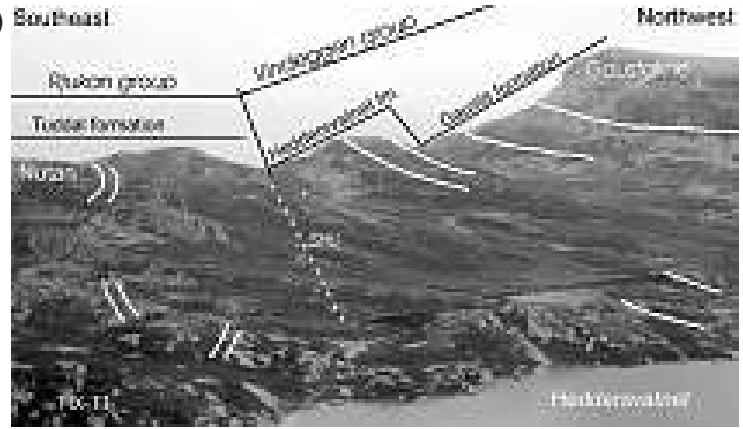

Fig. 4. Photographs of the lithologies of the Tuddal formation. For locations see Fig. 3. Number series on the outcrop photographs give station and photograph file numbers and UTM coordinates. a) Flow banded Tuddal formation lava. Hjartdøla. b) Lithophysa lava/breccia lava contact. Nutan. c) Lapilli tuff with near vertical bedding $\left(\mathrm{S}_{0}\right)$ and transverse foliation (local $\mathrm{S}_{1}$ ). SE of Heddersvatnet. d) Openly folded Tuddal debris flow unit at Nutan. e) View towards Nutan and Gaustakne from Heddersfjellet showing differences in bedding positions (white lines) in the Tuddal and Heddersvatnet formations across the unexposed sub-Heddersvatnet unconformity (SHU). indicates that the Vestfjorddalen valley represents a major fold zone with NW vergence.

Berner's (1993) observations at the southern margin of the Kovvatnet dome (Fig. 2) indicate a structural discordance between the Tuddal formation tuffs and the overlying Heddersvatnet formation arkosites, which together with the discussion above indicate that the structural history of the Rjukan group was different from that of the overlying Vindeggen group (cf. Richards, 1994, 1998).

\section{The Heddersvatnet Formation}

The Heddersvatnet formation is best exposed at the southern part of Heddersfjellet where almost a complete section is exposed although it often is difficult to locate the Tuddal formation/Heddersvatnet formation contact (see next chapter). The section starts with volcaniclastic pebbly-cobbly arkosites or conglomerates/sedimentary breccias with clasts of diverse Tuddal volcanites. Debris flow deposits with Tuddal 
a)

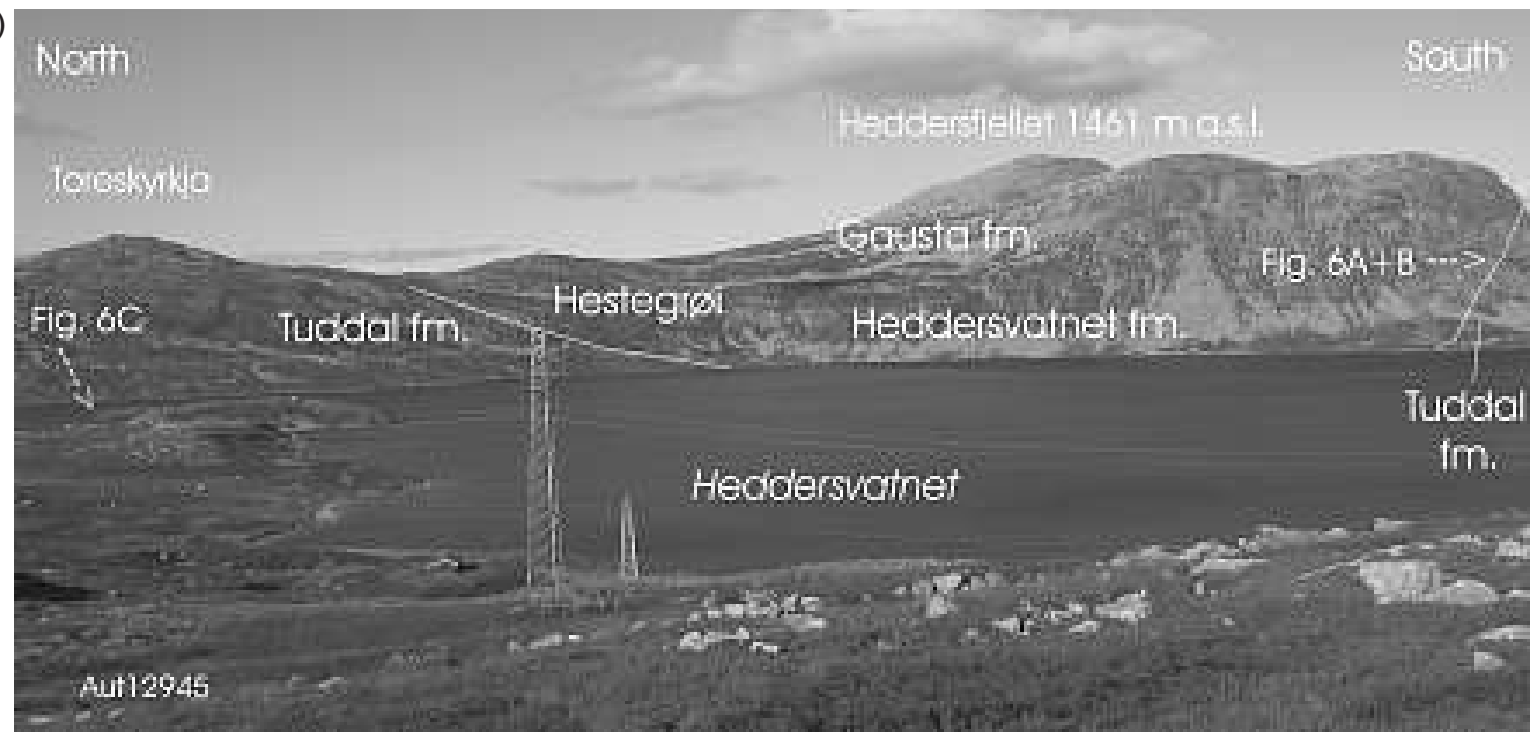

b)

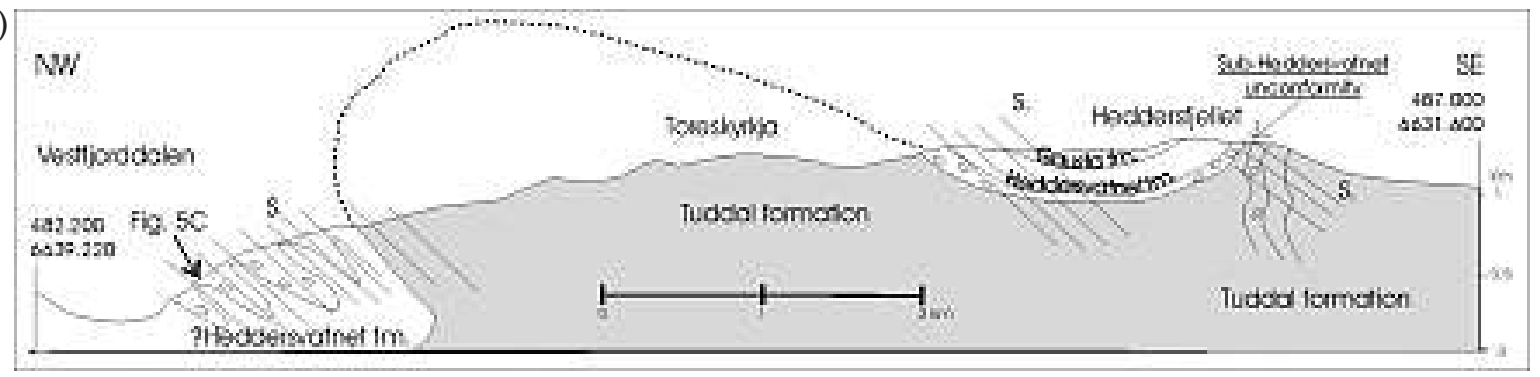

c)

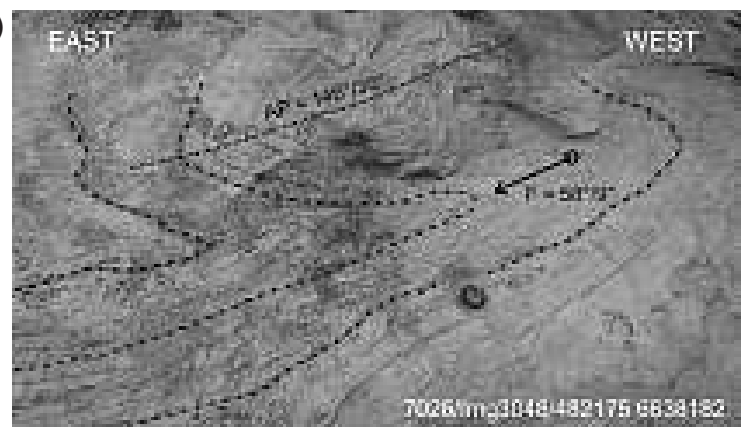

Fig. 5. Structure along the Heddersfjellet - Vestfjorddalen line. a) View of the Vindsjå syncline across Lake Heddersvatnet. White lines indicate the sub-Heddersvatnet unconformity. Locations of Figs. 6a-c are shown. b) Structural cross-section from Heddersfjellet to Vestfjorddalen showing $\mathrm{S}_{0} / \mathrm{S}_{1}$ (local notation) relation in the Tuddal formation and in the Heddersvatnet and Gausta formations of the Vindeggen group. c) Folded Heddersvatnet micaceous arkosite, southern flank of Vestfjorddalen.

volcanite pebbles and cobbles overlie these. This unit has an interbedded contact with the overlying arkosites, which become more mature upwards and pass into the quartzites of the Gausta formation. South of Heddersvatnet, the Heddersvatnet formation is mainly arkosic. Volcaniclastic conglomerates occur locally near the lower contact, but it is unsure if they belong to the Heddersvatnet formation or the Tuddal formation. At the northern side of Heddersvatnet, volcaniclastic conglomerates and debris flows are common in the lower part of the Heddersvatnet formation In addition to the clasts of the Tuddal formation, the conglomerate shown in Fig. 6c contains well-rounded, blastoclastic - granoblastic quartz-arenite pebbles indicating that the Heddersvatnet formation contains here material derived from other sources than the Tuddal formation even in its lowermost part.

North of Hjartdal, around the Kovvatnet dome, the Heddersvatnet formation was studied at several stations (Fig. 2). In general, the lithostratigraphy is 
Fig. 6. Photographs of the sub-Heddersvatnet unconformity (SHU) around Lake Heddersvatnet. For locations see Fig. 3. a) Erosional sub-Heddersvatnet unconformity between Tuddal formation porphyry and volcaniclastic conglomerate and Heddersvatnet formation arkosite dipping c. $48^{\circ}$ to $320^{\circ}$. Heddersfjellet. Position of Fig. 6b is shown. b) Sharp, erosional contact between a Tuddal formation lithophysa lava and a Heddersvatnet formation arkosite. c) Erosional unconformity (dashed) under a Heddersvatnet formation volcaniclastic conglomerate lying subhorizontally on a flow banded Tuddal formation lava. d) Sheared contact between a likely Heddersvatnet formation pebbly arkosite and Tuddal formation volcanic breccia and flow-banded lava. $\mathrm{S}_{\mathrm{C}}=\mathrm{C}$ (shear) plane of C/S fabric. NE of Hesjåbutindan.

similar to that around Heddersvatnet, but conglomerates are finer-grained or are missing in the lower part of the Heddersvatnet formation. On the other hand, when present, they may contain both felsic and mafic volcanic clasts, of which the latter have not seen around Heddersvatnet. The nature of the sub-Heddersvatnet unconformity also differs from that in the Heddersvatnet area (see below).

\section{Sub-Heddersvatnet unconformity}

\section{I. Definition}

The unconformity that separates the Vindeggen group from the underlying Tuddal formation around the Toreskyrkja and Kovvatnet domes (Fig. 2) is named the sub-Heddersvatnet unconformity after the lowermost formation of the Vindeggen group in this area.

\subsection{Heddersvatnet area}

Wyckoff (1934, p. 58) wrote that the contact between the (Tuddal formation) volcanics and the (Heddersvatnet formation) sediments appears to be transitional, i.e. the massive lowest beds of the sediments have a composition almost identical with that of the underlying volcanics - being made up of comminuted fragments of the groundmass material, and broken phenocrysts of quartz and feldspar. This holds to the cases where Heddersvatnet
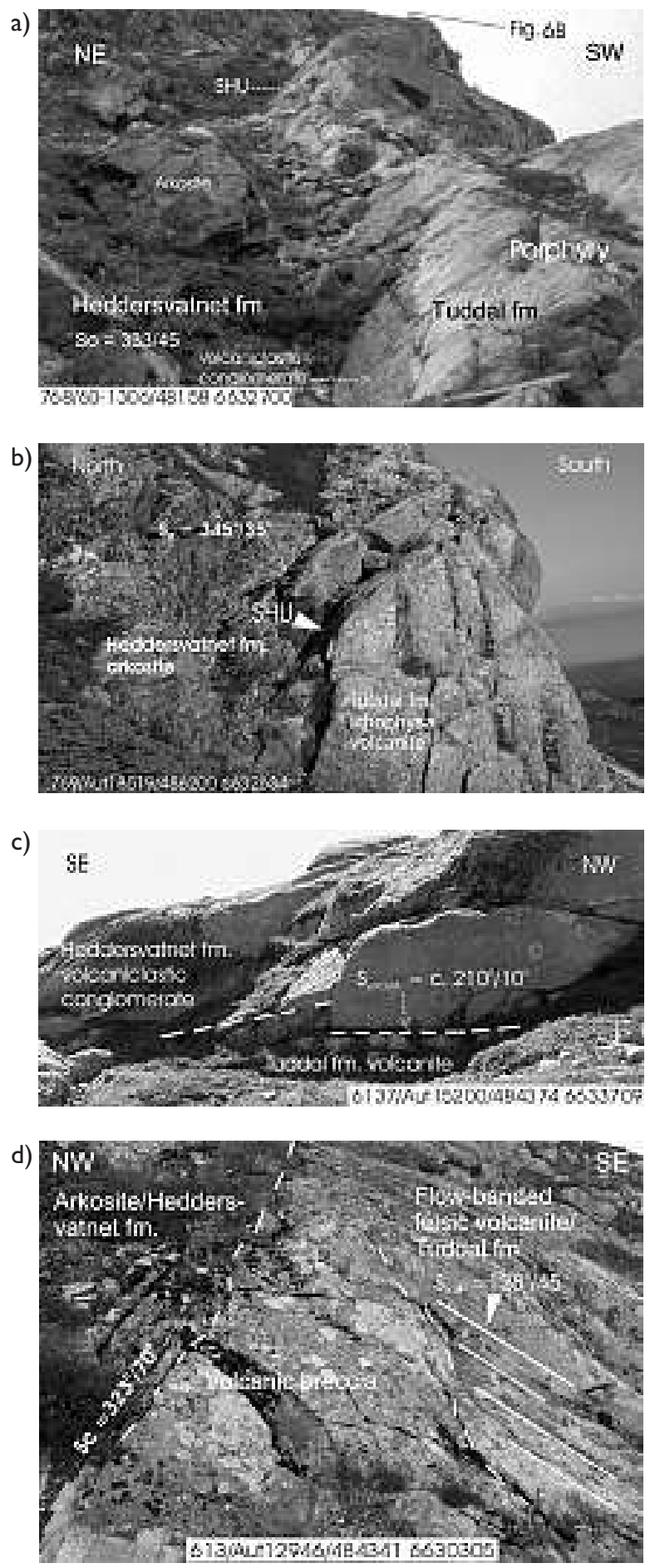

formation arkosite or sericite schist lies on porphyric - massive Tuddal formation volcanite, especially if the rocks are foliated. The ubiquitous lichen coating also hampers observations. For instance, al- 
though outcrops are rather abundant along the lakeshore in Figure 4e, the sub-Heddersvatnet unconformity cannot be located exactly.

There are, however, two localities where the subHeddersvatnet unconformity is well exposed. On the southern flank of Heddersfjellet, it is sharply erosional and most likely also an angular unconformity, as the Tuddal formation tuff bed south of it is near-vertical (Fig. 4c), whereas the Heddersvatnet formation represents part of the southeastern flank of the Vindsja syncline dipping to the NW (Figs. 5a \& b). The sub-Heddersvatnet unconformity forms a sharp, undulating surface dipping about $50^{\circ}$ to the NW and eroding obliquely a Tuddal formation volcaniclastic conglomerate, porphyry (Fig. 6a) and lithophysa rock (Fig. 6b) upwards from the level of Lake Heddersvatnet. These observations indicate that a c. $45^{\circ}$ angular discordance may occur between the Tuddal and Heddersvatnet formations at this locality (Fig. 5b).

The second locality where the sub-Heddersvatnet unconformity is well exposed is an outcrop on the northern shore of Heddersvatnet. Here a Heddersvatnet formation cobble conglomerate lies on a Tuddal formation flow banded lava. The sub-Heddersvatnet unconformity is sharp, erosional and dips shallowly (c. $10^{\circ}$ ) to the SW (Fig. 6c).

\subsection{Station $6 / 3$}

C. $2 \mathrm{~km}$ SSE of Heddersvatnet, near Hesjåbutindan, at station 613 (Fig. 3), a pebbly arkosite is in contact with a Tuddal formation flow banded lava and breccia (Fig. 6d). The contact is, however, sheared, and poorly visible. A similar Tuddal formation / Heddersvatnet formation relationship is obvious also on nearby outcrops, but the $1145+3 /-2$ Ma old (Dahlgren et al., 1990b) Hesjåbutindan gabbro intruded along the contact hinders direct observations (Fig. 3). Southwest of this locality, the sub-Heddersvatnet unconformity and Heddersvatnet formation are offset by the Marigrønutan fault (Fig. 2), but they are visible along the southwestern margin of the Kovvatnet dome to be described in the next section.

\subsection{Skjesvatnet-Hjartdøla-Kyrkjefjell-Tinnsjö contact zone}

The Tuddal formation/Heddersvatnet formation contact, often marked by conglomerates, has been accurately mapped around the Kovvatnet dome by Dons (1961) and Dons \& Jorde (1978). A small, fresh road cut on the SE shore of Lake Skjesvatnet (station 5096 in Fig. 2) shows how a homogeneous Tuddal formation porphyry passes gradually into the overlying Heddersvatnet formation sericite schist-sericite quartzite (Figs. 7a, b). The porphyry is blastoporphyric with quartz and feldspar phenocrysts in a groundmass altered to fine-grained sericite-quartz mass (Fig. 7c). The quartz phenocrysts are broken and the fractures are filled by sericite (Fig. 7c). The contact rock against the Heddersvatnet formation schist resembles macroscopically the porphyry, but under a microscope its shows clear clastic texture with both well-preserved and angular quartz-phenocryst clasts in sericite-rich matrix (Fig. 7d). The overlying sericite schist contains a few quartz-phenocryst clasts or their fragments in a fine-grained sericite-quartz host rock. It is dark grey due to opaque pigment and contains abundant accessory zircon and tourmaline (Fig. 7e). Faint bedding is visible in the rock, which passes upwards into a sericite quartzite with lone felsic volcanite pebbles. As the contact is gradual and the contact rock is clearly enriched in sericite (in aluminium), the latter is interpreted as an in situ, or lightly reworked (?kaolin) weathering product of the Tuddal formation porphyry. Consequently, this part of the sub-Heddersvatnet unconformity records a weathering crust developed upon the Tuddal formation. An interesting question is when the phenocrysts in the porphyry were broken. The very angular quartz clasts in the weathering crust indicate that it happened before the weathering of the porphyry, which could mean that the Tuddal formation was deformed before the deposition of the Heddersvatnet formation, cf. the structural discussion in the previous section.

The sub-Heddersvatnet unconformity can be followed from Skjesvatnet to the riverbed of Hjartdøla (station 78 in Fig. 2), where diverse volcanic con- 
a)

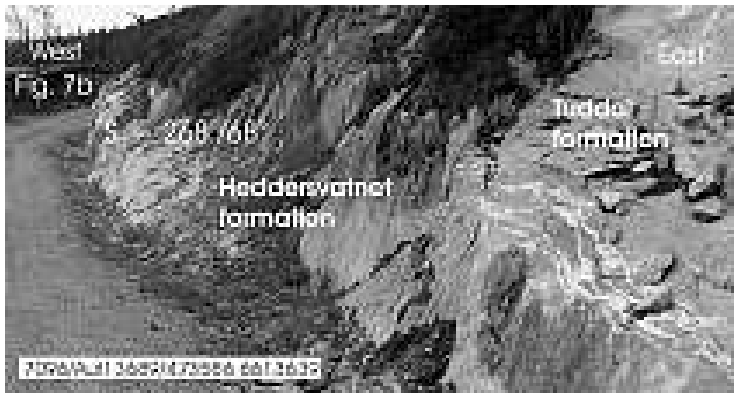

b)

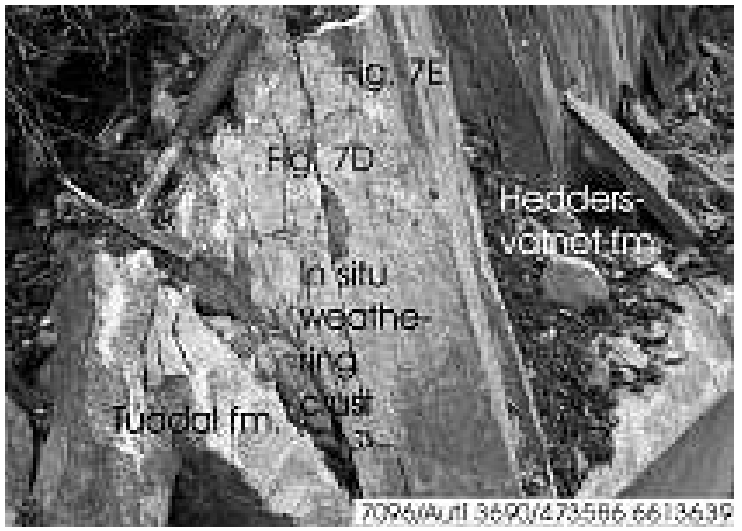

c)

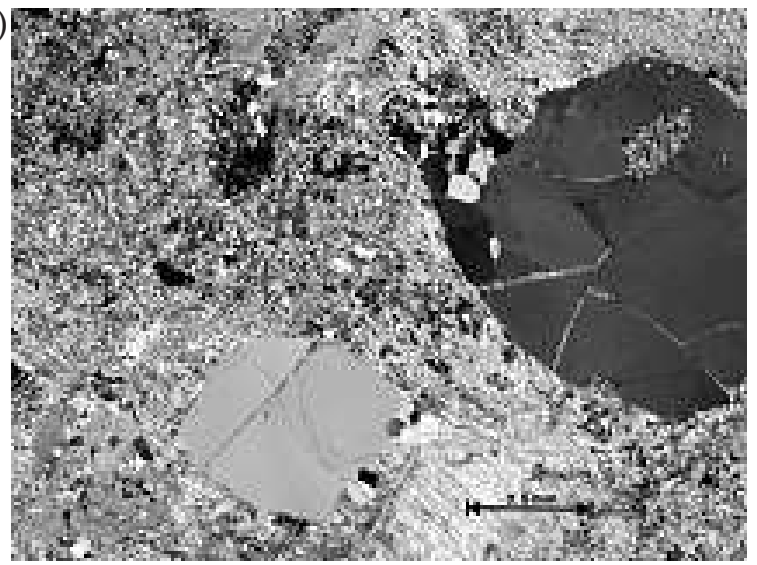

d)

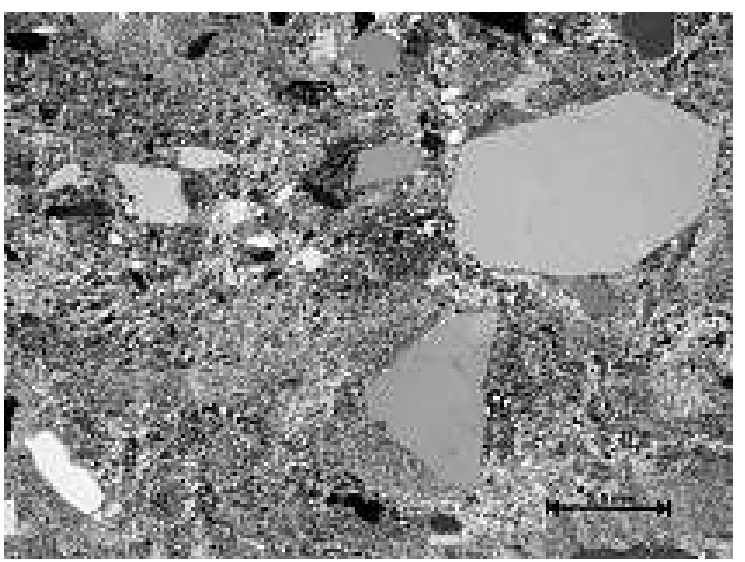

e)

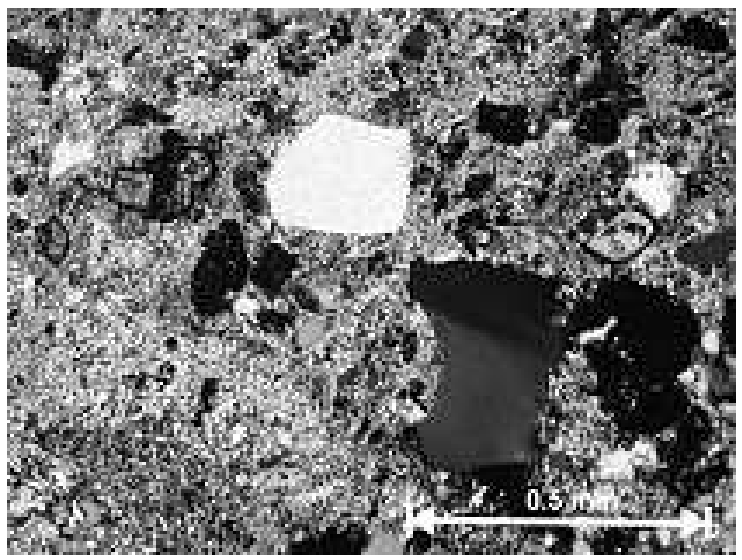

Fig. 7. Photographs and micophotographs of the Tuddal formation / Heddersvatnet formation contact on the Skjesvatnet road cut. a) Steep, gradual contact between the Tuddal and Heddersvatnet formations. White veins are quartz. Location of Fig. $7 b$ behind the curve is shown. b) Close up of the gradual Tuddal formation / Heddersvatnet formation contact showing locations of the samples in Figs. 7d and e. Microphotographs (two polars) of c) metamorphosed Tuddal formation porphyry, c. $5 \mathrm{~m}$ from the contact in Fig. 7b, d) in situ weathered porphyry, and e) overlying Heddersvatnet formation sericite schist.

glomerate and quartzite interbeds overlie Dons' (1960b, p. 18) red U3 porphyry (flow-banded lava in Fig. 4a). The Tuddal formation/Heddersvatnet formation contact is hard to locate as the river water has stained the outcrops. Neither an angular unconformity nor a tectonic discordance can bee seen, but the contact is most likely gradual or slightly erosional. Similar Tuddal formation / Heddersvatnet formation relationship seems to be also in the Hågåvatn area, c. 8 km NNE of Hjartdøla, where Berner (1993) considered the Rjukan/Seljord (Vindeggen) contact as conformable, although he also mentioned that his structural observations indicate a possible discordance between these units. Farther to the northeast, south of Kyrkjefjell (station 447 in Fig. 2), the sub-Heddersvatnet unconformity is not exposed, but a Tuddal formation lithophysa rock is overlain by a Heddersvatnet formation schist with quartz and microcline-phenocryst clasts in a sericite-rich host rock. This relation is similar to that at Skjesvatnet. At the eastern 
margin of the main Tuddal formation body, on both sides of Tinnsjö, in situ weathering crust and coarse conglomerates seem to be missing and the Heddersvatnet formation starts with arkosites (stations 3222 and 3255 in Fig. 2).

It is important to note, that no angular unconformity can directly be established in the cases described in this section as no bedding observation in the Tuddal formation basement is available. Thus, the Tuddal formation/Heddersvatnet formation relation is seemingly conformable or "disconformable" (cf. Table 1).

\section{Discussion}

As it is evident from Table 1, the existence of a major unconformity between the Rjukan and Vindeggen groups is an issue of longstanding controversial (Wyckoff, 1934; Dons, 1960a, b). Wyckoff (1934) based her opinion on rather detailed lithological and structural mapping of the Tuddal formation southeast of Gaustaråen (Fig. 2). Although the area she studied was rather small, an important component in her studies was measurements of bedding both in the Tuddal formation and the overlying quartzites, on the basis of which she drew her conclusion of the large angular unconformity. Dons (1961) mapped accurately the Rjukan group/Seljord group contact in a wide area, but unfortunately structural elements given are so few that no definite conclusions can be made. Starmer's (1993) and Menuge's and Brewer's (1996) opinions of the disconformity between the Rjukan and Seljord (Vindeggen) groups and Brewer's and Atkin's (1989) and Brewer's and Menuge's (1998) idea that there is only two periods of folding ("post-Seljord" and "post-Bandak") within the whole Telemark supracrustal package are based on short statements without any published structural geological data. Starmer (1993, p. 115) mentioned, however, that the Rjukan group has an erosional surface, commonly with metre-scale hollows, suggesting only short-term exposure at the surface. Dahlgren et al. (1990b) considered the Rjukan group/Seljord group contact as an angular unconformity along which a large metadiabase was emplaced. The $1145+3 /-2 \mathrm{Ma}$ old Hesjåbutindan gabbro (see the lower left corner in Fig. 3) represents a finger-like off-shot of this large sill. Sigmond et al. (1997) and Sigmond (1998) stated that the clean Seljord quartzites were deposited after a long quiet period, which almost completely levelled the old Rjukan rift-valley landscape.

In agreement with Wyckoff's (1934) original idea, the mapping and several contact observations done in this study indicate that the Tuddal formation (Rjukan)/ Heddersvatnet formation (Vindeggen) contact around the Toreskyrkja and Kovvatnet domes is more likely an angular unconformity (Fig. 5b) than a discordance or a minor, short-term erosional unconformity. How big a time gap it represents and the nature of the pre-Vindeggen deformation are open questions as the sedimentation age of the overlying Heddersvatnet formation is unknown and the structure of the Rjukan group has not been studied on a regional scale. The ages of the Tuddal volcanite (Dahlgren et al., 1990a; Sigmond, 1998) and a rhyodacite of the Nore group (Bingen et al., 2003) limit the sedimentation of the whole Vindeggen group between c. $1.51 \mathrm{Ga}$ and c. $1.17 \mathrm{Ga}$, which only give a rough view of c. $0.34 \mathrm{Ga}$ for the sub-Heddersvatnet unconformity time gap.

Richards' (1998) suggestion that the volcanics of the Rjukan group were folded before the deposition of the Seljord (Vindeggen) group is based on the structural observations across the Rjukan/Seljord contact in the Numedal area, about $40 \mathrm{~km}$ to NNE from Heddersvatnet. This is, however, the only locality where his $\mathrm{D}_{1}$ structures have been documented, but the roughly E-trending foliations in the Rjukan group west of this locality (Sigmond, 1998) seems to support this view. On the other hand, the statement that the Seljord group in the Numedal area begins with quartzite-pebble conglomerates (Richards, 1998 p. 123, cf. Sigmond, 1998) indicates that the quartzite in question could belong to the Lifjell group and consequently, this contact would not represent the sub-Heddersvatnet unconformity, but the younger sub-Lifjell unconformity. Clearly, studies based on mapping along profiles are not sufficient, but system- 


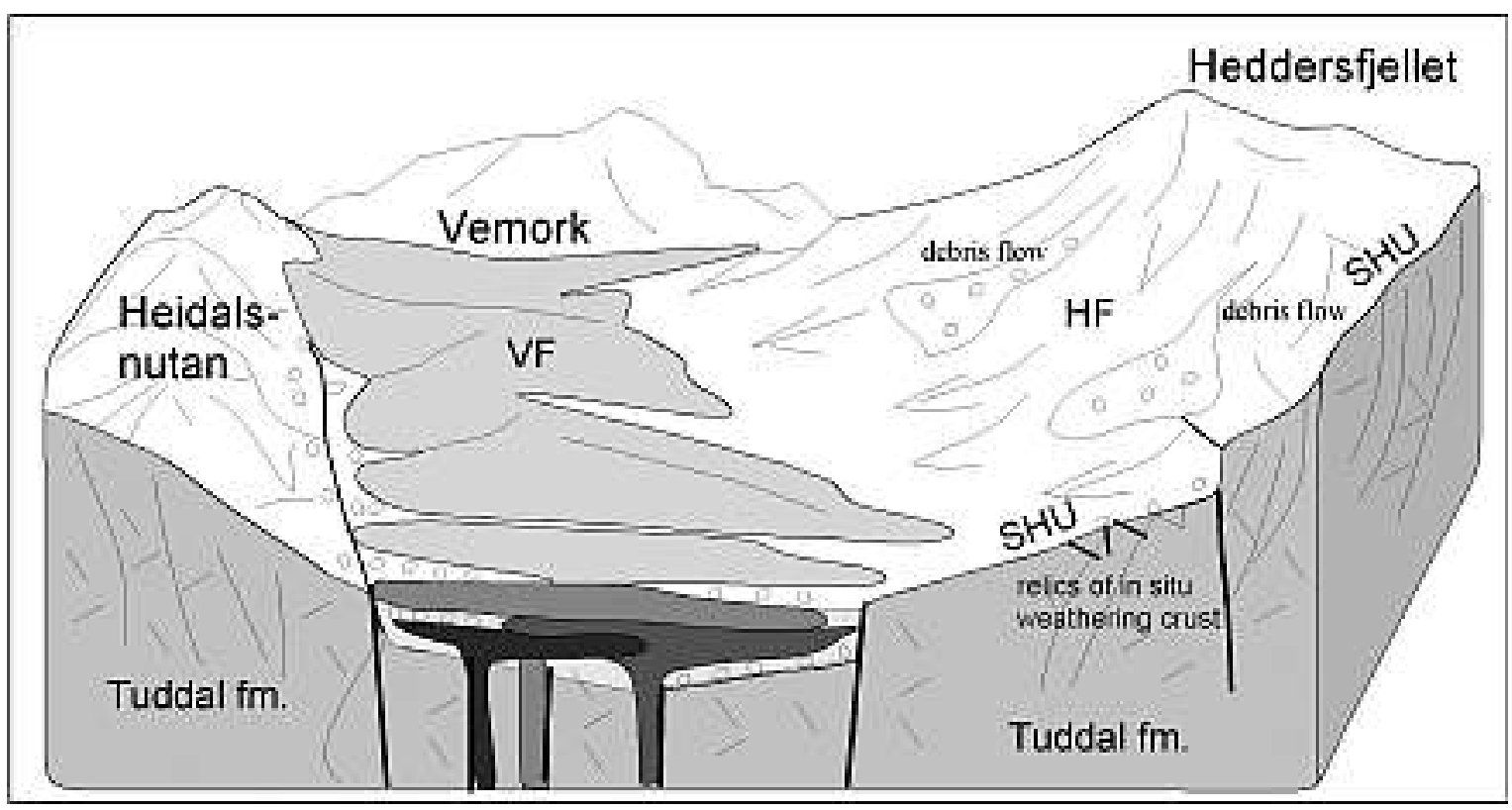

Fig. 8. Sketch showing the sub-Heddersvatnet unconformity (SHU) as a palaeosurface developed on the deeply eroded Tuddal formation (TF) around and on Heddersfjellet. The sub-Heddersvatnet unconformity may continue either under or above the Vemork formation (VF) (see legend in Fig. 2 and discussion in the text). HF = Heddersfjellet formation.

atic, outcrop-by-outcrop structural studies are needed in order to find out the relative importance of major folding (Wyckoff, 1934; Dons, 1960a, b), fault tectonics, (Falkum \& Petersen, 1980) or post-Rjukan sagging (Falkum, 1985) in the formation of the subHeddersvatnet unconformity.

Open questions are how the sub-Heddersvatnet unconformity is related to the contact between the Tuddal and Vemork formations around the Vårskarven and Heidalsnutan-Hortenuten domes and the contact between the Vemork formation and the Vindeggen group west of the Gausta fault (Fig. 2, see different opinions in Table 1). Laajoki (2003) stated that the Heddersvatnet and Vemork formations interfinger, which would indicate that the sub-Heddersvatnet unconformity continues under the latter formation. Palaeocurrent observations around Heddersvatnet show that the fluvial transportation during the deposition of the Heddersvatnet formation was towards southwest-west. This indicates that the eastern part of the area formed a highland or rift solder, which could have been exposed for erosion for a much longer time than the western part, where the Vemork lavas were extruded almost directly on the Tuddal formation in an axial rift zone. Thus, the time gap the sub-Heddersvatnet unconformity (as defined before) stands for may be larger than the one represented by its western correlative. The latter is under a closer study.

\section{Conclusions}

As Wyckoff (1934) and Dons (1960a, b) have proposed, the sub-Heddersvatnet unconformity most likely represents a deep erosional palaeosurface developed upon the folded Tuddal formation. Regionally, it represents an angular unconformity, which locally is identified either as a sharp erosional surface with irregular palaeorelief (Fig. 6) or as in situ preHeddersvatnet formation weathering crust developed on it (Fig. 7). In the study area, around the Toreskyrkja and Kovvatnet domes (Fig. 2), the sub-Heddersvatnet unconformity can be understood as a palaeosurface developed on a landscape floored by the de- 
formed and deeply eroded Tuddal formation (Fig. 8, cf. Wyckoff, 1934; Sigmond et al., 1997; Sigmond, 1998; Richards, 1994, 1998).

\section{Acknowledgements}

This study is part of the joint research between the Department of Geology of the University of Oulu and the University of Oslo. The Academy of Finland, the Research Council of Norway (project 154219/432), and the Geological Survey of Norway (project No. 265900) have supported it financially. Bernard Bingen and Åke Johansson are acknowledged for their constructive reviews.

\section{References}

Andersen, T., 2003. Sectors, segments and terranes. Towards a consistent terrane analysis of the SW Baltic Shield? NGF Abstracts and Proceedings 1/2003, 1-2.

Andersen, T. \& Laajoki, K., 2003. Provenance characteristics of Mesoproterozoic metasediments from Telemark, South Norway. a Nd-isotope mass balance model. Precambrian Research 126, 95-122.

Berner, T., 1993. En petrologisk undersøkelse af Midt-Proterozoiske sure vulkanitter I Telemark, Sydnorge. Specialeafhandling, Geologisk Institut, Aarhus Universitet, $104 \mathrm{p}$.

Bingen, B., Birkeland, A., Nordgulen, Ø. \& Sigmond, E.M.O., 2001. Correlation of supracrustal sequences and origin of terranes in the Sveconorwegian orogen of SW Scandinavia. SIMS data on zircon in clastic metasediments. Precambrian Research 108, 293-318.

Bingen, B., Nordgulen, Ø., Sigmond, E.M.O., Tucker, R., Mansfeld, J. \& Högdahl, K., 2003. Relations between 1.19-1.13 Ga continental magmatism, sedimentation and metamorphism, Sveconorwegian province, S Norway. Precambrian Research 124, 215-241.

Bingen, B., Skår, Ø., Marker, M., Sigmond, E. M.O., Nordgulen, Ø., Ragnhildstveit, J., Mansfeld, J., Tucker, R. D. \& Liégeois, J.-P., 2005. Timing of continental building in the Sveconorwegian orogen, SW Scandinavia. Norwegian Journal of Geology 85, 87-116.

Brewer, T.S., 1985. Geochemistry, geochronology and tectonic setting of the Proterozoic Telemark supracrustals, Southern Norway. PhD Thesis, University of Nottingham, 380 p.

Brewer, T.S. \& Atkin, B.P., 1989. Elemental mobilities produced by low-grade metamorphic events; a case study from the Proterozoic supracrustals of southern Norway. Precambrian Research 45, 143-158.

Brewer, T.S. \& Menuge, J.F., 1998. Metamorphic overprinting of $\mathrm{Sm}-\mathrm{Nd}$ isotopic systems in volcanic rocks.
The Telemark Supergroup, southern Norway. Chemical Geology 45, 1-16.

Brewer, T.S., Åhäll, K.-I., Menuge, J.F., Storey, C.D. \& Parrish, R.R., 2004. Mesoproterozoic bimodal volcanism in SW Norway, evidence for recurring pre-Sveconorwegian continental margin tectonism. Precambrian Research 134, 249-273.

Cash, R.A.F. \& Wright, J.V., 1988. Volcanic successions. Unwin Hyman Ldt., 519 p.

Dahlgren, S.H., Heaman, L. \& Krogh, T.E., 1990a. Geological evolution and U-Pb geochronology of the Proterozoic central Telemark area, Norway (abstract). Geonytt $17(1), 38$.

Dahlgren, S.H., Heaman, L., Krogh, T.E., 1990b. Precise $\mathrm{U}-\mathrm{Pb}$ zircon and baddeleyite age of the Hesjåbutind gabbro, central Telemark area, southern Norway. Geonytt $17(1), 38$.

Dons, J.A., 1960a. Telemark supracrustals and associated rocks. In: Holtedahl, O. (ed.) Geology of Norway. Norges Geologiske Undersøkelse 208, 49-58.

Dons, J.A., 1960b. The stratigraphy of supracrustal rocks, granitization and tectonics in the Precambrian Telemark area. Southern Norway. Norges Geologiske Undersøkelse $212 \mathrm{~h}, 1-30$.

Dons, J.A., 1961. Berggrunnskart. Rjukan; 1.100 000. Norges Geologiske Undersøkelse. Trondheim.

Dons, J.A. \& Jorde, K., 1978. Geologisk kart over Norge, berggrunnskart Skien; 1.250,000. Norges Geologiske Undersøkelse, Trondheim.

Falkum, T., 1985. Geotectonic evolution of southern Scandinavia in light of a late Proterozoic plate-collision. In: Tobi, A.C., \& Touret, J.L.R. (eds.) The Deep Proterozoic Crust in the North Atlantic Provinces, 309-322.

Falkum, T. \& Petersen, J.S., 1980. The Sveconorwegian orogenic belt, a case of late-Proterozoic plate-collision. Geologische Rundschau 69, 622-647.

Gaál, G. \& Gorbatschev, R., 1987. An outline of the Precambrian evolution of the Baltic Shield. Precambrian Research 35, 15-52.

Jackson, J. A., 1997. Glossary of Geology, $4^{\text {th }}$ edition. American geological Institute. Falls Church, Virginia, 769 p.

Laajoki, K., 2002. The Mesoproterozoic sub-Heddal unconformity, Sauland, Telemark, south Norway. Norsk Geologisk Tidsskrift 82, 139-152

Laajoki, K., 2003. Relationship between the Mesoproterozoic Rjukan and Vindeggen groups in Telemark, south Norway. NGF Abstracts and Proceedings 1, 2003, 5152

Laajoki, K. \& Lamminen, J. T., 2005. Volcanic-sedimentary evolution of the Mesoproterozoic Telemark supracrustals, south Norway. Abstracts and Proceedings of the Geological Society of Norway 1/2005, 58-59.

Laajoki, K., Corfu, F. \& Andersen, T., 2002. Lithostratigraphy and U-Pb geochronology of the Telemark supracrustals in the Bandak-Sauland area, Telemark, South Norway. Norsk Geologisk Tidsskrift 82, 119-138. 
Lamminen, J.T. \& Laajoki, K., 2004. Facies analysis of the Mesoproterozoic Røynstaul formation, Telemark, South Norway. 32 ${ }^{\text {nd }}$ IGC, Florence 2004, Abstracts (part 2), 1290.

Menuge, J.F. \& Brewer, T.S., 1996. Mesoproterozoic anorogenic magmatism in southern Norway. In: Brewer, T.S. (ed.) Precambrian crustal evolution in the North Atlantic regions. Geological Society Special Publication $112,275-295$.

Nystuen, J.P., (ed.) 1986. Regler og råd for navnsetting av geologiske enheter i Norge. Av Norsk stratigrafisk komité. Norsk Geologisk Tidsskrift 66, Suppl. 1, 96 p.

Nystuen, J.P., (ed.) 1989. Rules and recommendations for naming geological units in Norway by the Norwegian Committee on Stratigraphy. Norsk Geologisk Tidsskrift 69, Suppl. 2, 111 p.

Richards, F. L., 1994. Sveconorwegian deformation and mega-scale fold interference in the Telemark region of south Norway. Terra Nova, Abstract Supplement 2, 16.

Richards, F. L., 1998. The structural geology of the Telemark supracrustal suite, South Norway. PhD Thesis. University College Cork. 296 p + 12 appendixes.
Sigmond, E.M.O., 1998. Geologisk kart over Norge, Berggrunnskart ODDA, M 1.250 000. Norges Geologisk Undersøkelse, Trondheim.

Sigmond, E.M.O., Gjelle, S.\& Solli, A., 1997. The Rjukan Proterozoic rift basin, its basement and cover, volcanic, and sedimentary infill, and associated intrusions. Norges Geologiske Undersøkelse, Bulletin 433, 6-7.

Starmer, I.C., 1993. The Sveconorwegian orogeny of southern Norway, relative to deep crustal structures and events in the North Atlantic Proterozoic Supercontinent. Norsk Geologiske Tidsskrift 73, 109-32.

Werenskiold, W., 1910. Om Øst-Telemarken. Norges Geologiske Undersøkelse 52, 69 p.

Wyckoff, D., 1934. Geology of the Mt. Gausta Region in Telemark, Norway. Norsk Geologisk Tidsskrift 13, 172 . 